\title{
Commentary: The oxygen metabolism of the brain transparent
}

\author{
Manan Desai, MD, and Can Yerebakan, MD
}

\footnotetext{
From the Department of Cardiovascular Surgery, Children's National Heart Institute, Children's National Health System, The George Washington University School of Medicine and Health Sciences, Washington, DC. Disclosures: Authors have nothing to disclose with regard to commercial support.

Received for publication Sept 11, 2019; revisions received Sept 11, 2019; accepted for publication Sept 11, 2019; available ahead of print Nov 22, 2019.

Address for reprints: Can Yerebakan, MD, Cardiovascular Surgery, Children's National Heart Institute, Children's National Health System, The George Washington University School of Medicine and Health Sciences, 111 Michigan Ave NW, Washington, DC, 20010 (E-mail: cyerebakan@childrensnational.org).

J Thorac Cardiovasc Surg 2020;159:2024-5

$0022-5223 / \$ 36.00$

Copyright $(2019$ Published by Elsevier Inc. on behalf of The American Association for Thoracic Surgery https://doi.org/10.1016/j.jtcvs.2019.09.052
}

Brain development peaks in later half of gestation and continues at a rapid pace for a few months postnatally. ${ }^{1}$ An important premise of early correction of congenital heart disease is therefore to provide an immediate normal cerebral circulation. ${ }^{2}$ While early surgical outcome in congenital heart disease continues to excel, long-term neurodevelopmental outcome of our patients has become one of the most important metrics in congenital heart disease.

In this issue of the Journal, Cheng and colleagues ${ }^{3}$ have compared noninvasively measured cerebral oxygen metabolism among a mixed patient population with congenital heart disease and a control group in the pre- and postoperative settings. The authors have to be commended for their research aiming for new paradigms in neuromonitoring for congenital heart disease. The limited number of patients with various diagnoses and challenges in controlling numerous confounding factors should not shadow their immense effort to gain insights to brain oxygen use. In the preoperative measurements, both patients with d-transposition of great arteries (d-TGA) as well as singleventricle patients have demonstrated an increase oxygen extraction fraction compared with controls. This, in conjunction with brain-sparing changes in cerebral blood flow regulation described by Donofrio and colleagues, ${ }^{4}$ seems to be a compensation by nature for impaired cerebral oxygen delivery. The authors observed a drop in cerebral blood flow index postoperatively in biventricular patients and d-TGA groups as opposed to their preoperative values. Cerebral oxygen metabolism index had an accompanying postoperative decrease in patients with d-TGA only.

Congenital heart disease is a factor for significant abnormal brain development, with more than $50 \%$ patients demonstrating neurologic abnormalities. ${ }^{5}$ Intrauterine levels of cerebral blood flow, arterial oxygen saturation, oxygen extraction, and cardiac output seem to affect neurodevelopmental outcome in this patient population.,

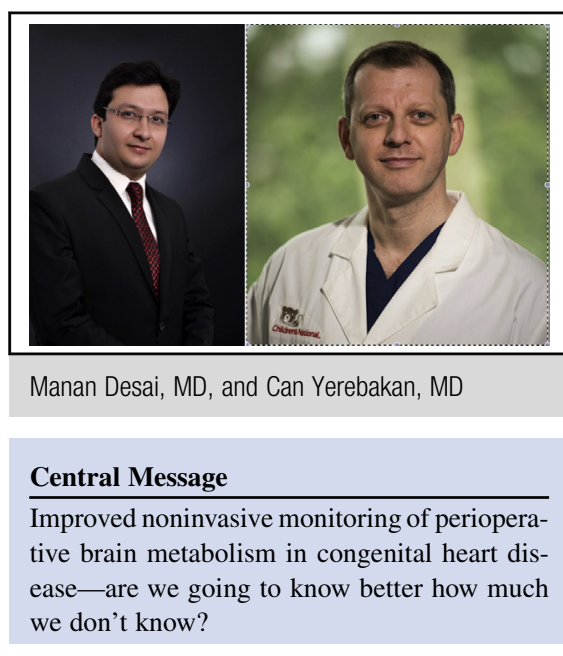

See Article page 2012.

Furthermore, the effects may be compounded by an underlying genetic predisposition to abnormal neurologic development. Developmental delay in patients with trisomy 21 and deletion of 22q11 underscore that certain genes are at the intersection of heart and brain development. Novel magnetic resonance imaging techniques have confirmed abnormal in utero brain development in children with congenital heart disease.

Besides innate patient factors, the strategies in surgical repair for congenital heart disease should be carefully evaluated for their impact on their neurodevelopmental outcome. Several factors involved in cardiopulmonary bypass, like temperature, hematocrit, $\mathrm{pH}$, and perfusion pressure, are known to affect cerebral blood flow and metabolism. ${ }^{8-10}$ Risk of microemboli during cardiopulmonary bypass, postoperative length of intensive care stay, cardiac arrest, and use of extracorporeal membrane oxygenation support may additionally increase the risk of neurologic injury. ${ }^{11}$ Indeed, several studies have demonstrated long-term neurologic sequelae in patients of congenital heart disease following surgical correction. ${ }^{12}$ Although it is known that there is a connection between neurodevelopment and congenital cardiac surgery, the modalities of neuromonitoring in the perioperative period are less well established.

Hence, while patient-specific factors may be challenging to correct, efforts to seek an effective reduction of perioperative factors that influence later long-term neurodevelopmental outcome remain of utmost importance. Noninvasive methods that are proposed in this current study 
may indeed allow determining the timing and mechanisms of perioperative alterations in brain metabolism. Improving suboptimal neurodevelopmental outcomes in congenital heart disease is an ongoing herculean effort involving multiple disciplines. Pharmacologic and regenerative interventions are extensively being studied for their potential neuroprotective benefits. ${ }^{13-15}$ These efforts in conjunction with advances in neuromonitoring hold promise of enabling better neurodevelopmental outcome of pediatric patients with congenital heart disease.

\section{References}

1. Stiles J, Jernigan TL. The basics of brain development. Neuropsychol Rev. 2010; 20:327-48.

2. Jonas RA. Optimal timing for congenital cardiac surgery: the importance of early primary repair. In: Jonas RA, ed. Comprehensive Surgical Management of Congenital Heart Disease. 2nd ed. London: CRC Press; 2014:225-6.

3. Cheng HH, Ferradal SL, Vyas R, Wigmore D, McDavitt E, Soul JS, et al. Abnormalities in cerebral hemodynamics and changes with surgical intervention in neonates with congenital heart disease. J Thorac Cardiovasc Surg. 2020;159: 2012-21.

4. Donofrio MT, Bremer YA, Schieken RM, Gennings C, Morton LD, Eidem BW, et al. Autoregulation of cerebral blood flow in fetuses with congenital heart disease: the brain sparing effect. Pediatr Cardiol. 2003;24:436-43.

5. Limperopoulos C, Majnemer A, Shevell MI, Rosenblatt B, Rohlicek C, Tchervenkov C. Neurologic status of newborns with congenital heart defects before open heart surgery. Pediatrics. 1999;103:402-8.
6. Kaltman JR, Di H, Tian Z, Rychik J. Impact of congenital heart disease on cerebrovascular blood flow dynamics in the fetus. Ultrasound Obstet Gynecol. 2005; 25:32-6.

7. Miller SP, McQuillen PS, Hamrick S, Xu D, Glidden DV, Charlton N, et al Abnormal brain development in newborns with congenital heart disease. N Engl J Med. 2007;357:1928-38.

8. Newburger JW, Jonas RA, Wernovsky G. A comparison of the perioperative neurologic effects of hypothermic circulatory arrest versus low-flow cardiopulmonary bypass in infant heart surgery. J Pediatr. 1994;124:823.

9. Shin'oka T, Shum-Tim D, Jonas RA, Lidov HG, Laussen PC, Miura T, et al Higher hematocrit improves cerebral outcome after deep hypothermic circulatory arrest. J Thorac Cardiovasc Surg. 1996;112:1610-21.

10. du Plessis AJ, Jonas RA, Wypij D, Hickey PR, Riviello J, Wessel DL, et al. Perioperative effects of alpha-stat versus $\mathrm{pH}$-stat strategies for deep hypothermic cardiopulmonary bypass in infants. J Thorac Cardiovasc Surg. 1997;114:991-1001.

11. Ballweg JA, Wernovsky G, Gaynor JW. Neurodevelopmental outcomes following congenital heart surgery. Pediatr Cardiol. 2007;28:126-33.

12. Bellinger DC, Wypij D, Kuban KC, Rappaport LA, Hickey PR, Wernovsky G, et al. Developmental and neurological status of children at 4 years of age after heart surgery with hypothermic circulatory arrest or low-flow cardiopulmonary bypass. Circulation. 1999;100:526-32.

13. Romanowicz J, Leonetti C, Dhari Z, Korotcova L, Ramachandra SD, Saric N, et al. Treatment with tetrahydrobiopterin improves white matter maturation in a mouse model for prenatal hypoxia in congenital heart disease. Am Heart $J$ 2019;8:e012711.

14. Andropoulos DB, Brady K, Easley RB, Dickerson HA, Voigt RG, Shekerdemian LS, et al. Erythropoietin neuroprotection in neonatal cardiac surgery: a phase I/II safety and efficacy trial. J Thorac Cardiovasc Surg. 2013;146:124-31.

15. Kapani N, Maeda T, Sarkislali K, Dhari Z, Leonetti C, Ulrey R, et al. Mesenchymal stem/stromal cell therapy during pediatric cardiac surgery on neurogenesis in the porcine subventricular zone. Neurology. 2019;92(suppl 15):P5.6-055 